\title{
La conquista de Sevilla por Fernando III (646 h/1248). Nuevas pro- puestas a través de la relectura de las fuentes árabes*
}

\author{
Alejandro García Sanjuán ${ }^{1}$ \\ Universidad de Huelva \\ sanjuan@uhu.es
}

RESUMEN: La conquista de Sevilla por Fernando III en 646 h/1248 constituye uno de los hechos decisivos del proceso de expansión política y territorial desarrollado por la Corona de Castilla durante el siglo XIII. En este artículo se plantea, por vez primera, un análisis global de la información que las fuentes árabes aportan sobre este episodio, la cual no ha sido, hasta el momento, objeto de un tratamiento pormenorizado. Esta información resulta ampliamente compatible con la de las fuentes cristianas y posee un particular interés en relación con tres aspectos especificos: la cronología de la conquista y la secuencia del traspaso del control de la ciudad de manos musulmanas a cristianas, la visión de los vencidos y el destino de la población musulmana.

\section{Palabras Clave: Sevilla; Fernando III; Fuentes árabes; Visión de los vencidos; Mudéjares.}

The Conquest of Seville by Ferdinand III (646 h/1248). New Proposals through the Reading of the Arabic Sources

ABSTRACT: The conquest of Seville by Ferdinand III of Castile in 646 h/1248 is one of the decisive events of the process of political and territorial expansion developed by the Crown of Castile during the thirteenth century. This article presents, for the first time, a comprehensive analysis of the informa-

${ }^{*}$ Este trabajo ha sido realizado en el marco del Proyecto de Investigación financiado por el Ministerio de Economía, Industria y Competitividad con el título de «Génesis y desarrollo de la guerra santa cristiana en la Edad Media del occidente peninsular» (HAR2012-32790), dirigido por el Dr. Carlos de Ayala (Universidad Autónoma de Madrid).

1 ORCID iD: http://orcid.org/0000-0002-7889-5938. 
tion that Arab sources bring about this episode, which has not been hitherto the subject of a detailed treatment. This information, broadly compatible with Christian sources, has a particular interest in relation to three specific issues: the chronology of the conquest and the handover process of the city from Muslims to Christians, the vision of the vanquished and the fate of the Muslim population.

KEY WORDS: Seville; Ferdinand III; Arabic Sources; Vision of the vanquished; Mudéjar community.

CÓMO CITAR ESTE ARTÍCULO/CITATION: García Sanjuán, Alejandro, «La conquista de Sevilla por Fernando III (646h/1248). Nuevas propuestas a través de la relectura de las fuentes árabes», Hispania, 77/255 (Madrid, 2017): 11-41. doi: 10.3989/hispania. 2017.001

\section{LAS FUENTES ÁRABES EN LA TRADICIÓN HISTORIOGRÁFICA SOBRE LA CON- QUISTA DE SEVILLA}

La conquista de Sevilla cuenta con una tradición historiográfica relativamente amplia cuyos trabajos más importantes se remontan a la segunda mitad del siglo XX. No pretendo revisar aquí toda esta tradición, sino que, desde una perspectiva mucho más específica, me limitaré a intentar establecer una caracterización de la forma en la que los textos árabes han sido integrados en la evolución de estos estudios, con el fin de enmarcar de forma adecuada el análisis posterior de las fuentes árabes.

La historiografía más clásica o tradicional la conforman trabajos elaborados por medievalistas que, en general, han realizado un uso del registro literario árabe que puede calificarse como indirecto y restrictivo. En efecto, las fuentes manejadas son, en exclusiva, las de naturaleza narrativa, debido, sobre todo, a que se trata de las únicas que han sido traducidas, casi en su totalidad, a distintos idiomas europeos. Asimismo, la relevancia atribuida a estos textos en el análisis ha sido secundaria, asignándose un valor superior a las fuentes cristianas. Ambos aspectos permiten entender la primacía del relato elaborado por el sector de los conquistadores, en detrimento del correspondiente a los vencidos.

Los primeros trabajos de una entidad académica relevante se vinculan a la figura de Julio González. En el extenso estudio que precede a su edición del Repartimiento de Sevilla, publicado en 1951, dicho investigador menciona, en una nota, cinco fuentes árabes narrativas (al-Maqqarī, al-Himyarī, alNuwayrī, Ibn 'Id̄ārī e Ibn Jaldūn), las cuales utilizó, fundamentalmente, para fijar la cronología de la conquista. Cotejando las distintas fechas que se mencionan en ellas, el medievalista palentino concluía que «se puede deducir que 
la capitulación fue el 23 de noviembre y la entrega de la ciudad el 13 de enero $»^{2}$. Años más tarde, dicho investigador volvía a tratar el asunto, desde la misma perspectiva, en otra de sus obras más importantes, haciéndose eco de nuevo de la disparidad cronológica e insistiendo en que la fecha del 13 de enero apuntada como caída de la ciudad por dos autores árabes (Ibn 'Iḍārī e Ibn Jaldūn) «puede ser compatible» con la del 23 de noviembre como la de capitulación ${ }^{3}$.

En realidad, dicha disparidad cronológica de las fuentes árabes resulta más aparente que real, como pondré de manifiesto a continuación. De acuerdo con lo apuntado por J. González, las dos fechas que las mismas registran son compatibles, aunque de un modo distinto al indicado por el citado investigador, con la Estoria de España, que aporta el único relato elaborado por los conquistadores. Así lo revela una lectura atenta de los textos árabes en conjunción con la citada crónica alfonsí, si bien se trata de un aspecto que, hasta ahora, ha pasado prácticamente desapercibido en la historiografía.

Junto a la cuestión cronológica, J. González también se interesó por el problema del destino de la población local. Desde esta perspectiva, tomó en cuenta tanto ciertos testimonios poéticos árabes, supuestamente asociados a la caída de Sevilla, como las propias fuentes narrativas, de las que se sirvió para aportar algunos datos relativos a los últimos dirigentes de la ciudad islámica ${ }^{4}$.

A pesar de contarse entre los más importantes arabistas y medievalistas de su tiempo, tampoco Ambrosio Huici Miranda desarrolló un análisis amplio de los textos árabes sobre la caída de Išbīliya, cuestión a la que dedica apenas un breve párrafo, así como una algo más extensa nota, en su bien conocida Historia política del Imperio almohade, publicada en dos volúmenes a mediados de la década de $1950^{5}$.

Tras los trabajos de Julio González, el investigador que más se ha ocupado de la conquista de Sevilla ha sido, sin duda, M. González Jiménez, el cual ha tenido oportunidad de abordar su estudio en varias publicaciones de distinta naturaleza. Entre ellas destaca su monografía sobre el reinado de Fernando III, en la que dedica un espacio amplio a la toma de la ciudad. Su perspectiva respecto a las fuentes árabes coincide con la tradicional, como revela la consideración de la Estoria de España como «casi la única fuente de información $\mathrm{y}$, desde luego, la principal $»^{6}$. No obstante, en consonancia con la citada tradición, utiliza las fuentes árabes, tanto las narrativas como los testimonios

2 GONZÁLEZ, 1951, vol. 1: 214, nota $\mathrm{n}^{\circ} 218$.

3 GONZÁLEZ, 1980, vol. 1: 386, nota $\mathrm{n}^{\circ} 586$.

4 GONZÁLEZ, 1980, vol 1: 387-389.

5 HUICI MIRANDA, 1956-57, vol. 2: 540.

6 GONZÁLEZ JIMÉNEZ, 2006, 215. 
poéticos, aunque en este último caso, al igual que J. González, no los directamente vinculados con la caída de la ciudad 7 .

Si bien es cierto que en la perspectiva de estos trabajos las fuentes árabes quedan subordinadas a las castellanas, los citados investigadores manifiestan un interés por su análisis que, en cambio, no se aprecia en otros estudios dedicados a la figura de Fernando III, en los que dichos textos están casi totalmente ausentes, tal vez debido a su naturaleza divulgativa ${ }^{8}$.

El papel de las fuentes árabes comienza a experimentar algunos cambios a partir de las décadas de 1980 y 1990, cuando se publicaron los primeros estudios que superaban el límite de los textos narrativos, ampliando, así, la base empírica con la incorporación de otros distintos. Es cierto que la monografía sobre la Sevilla islámica de J. Bosch Vilà no aportó demasiadas novedades, pese a la condición de arabista del autor, algo explicable, de nuevo, por la naturaleza divulgativa de la obra, que se inserta en una amplia colección, integrada por varios volúmenes, sobre la Historia de Sevilla9 ${ }^{9}$.

Durante el citado período, el cambio más significativo se produce a través de las publicaciones de $\mathrm{R}$. Valencia ${ }^{10}$, las cuales han permitido una revalorización de las fuentes árabes, desde una doble perspectiva. En primer lugar, al situar el centro del análisis en estos textos y, por otro lado, al apelar, por vez primera, a la importancia de la información procedente de los denominados diccionarios biográficos o repertorios de ulemas ${ }^{11}$, aportando nuevos planteamientos hasta entonces no considerados en la tradición historiográfica previa. Sus trabajos, por lo tanto, constituyen contribuciones novedosas que han permitido un avance importante en el análisis de las fuentes árabes, si bien no agotan el aprovechamiento de esta clase de textos, según trataré de mostrar a continuación.

La rápida revisión historiográfica hasta aquí realizada permite afirmar dos aspectos sobre la utilización de las fuentes árabes respecto al estudio de la conquista de Sevilla. En primer lugar, el predominio de una perspectiva de análisis que podemos denominar clásica y cuya naturaleza debemos calificar de reduccionista, debido a que se atribuye a dichas fuentes una función secundaria respecto a las castellanas, limitándose, además, a los textos narrativos, así como a algunas referencias poéticas, cuya relación con la conquista

7 GONZÁLEZ JIMÉNEZ, 2006, 219 (Ibn `Idēārī) y 234 (poema de Ibn Sa Sād). En nota n ${ }^{\circ}$ 37 se citan los textos de al-Ḥimyarī e Ibn Abī Zaré, aunque de una forma algo confusa, tal vez debido a la similitud de sus respectivos títulos (al-Rawd al-mi țār y Raw

8 MARTÍNEZ DÍEZ, 1993, 210-224.

9 BOSCH VILÀ, 1984, 182-187.

10 VALENCIA, 1988; 1992; 1998; 2000. Añádase el artículo de BENABOUD, 2000.

11 Denominación que MANZANO, 2006, 368, considera más apropiada para este género de la literatura árabe clásica. 
no siempre está plenamente justificada. Por otro lado, la ausencia, hasta el momento, de un análisis global y pormenorizado del registro literario árabe en un marco comparativo respecto al relato de la Estoria de España.

El desarrollo de esta labor exige, en primer lugar, identificar dichos textos y establecer sus principales características, comparando, a continuación, la información que contienen con la de la Estoria de España. Sólo así será posible un aprovechamiento más amplio de las fuentes árabes, lo cual nos permitirá desvelar ciertos aspectos hasta ahora no tomados en consideración en la tradición historiográfica previa, sobre todo la amplia compatibilidad entre ambos registros literarios, árabe y castellano.

\section{LA EXCEPCIONALIDAD DE SEVILLA}

La primera constatación que debemos establecer radica en la singularidad del caso de Sevilla en el contexto del amplio proceso de conquistas territoriales llevadas a cabo por la Corona de Castilla durante el siglo XIII ${ }^{12}$. De todas las grandes ciudades que pasaron al dominio castellano en este período (Córdoba, Jaén, Sevilla, Niebla, Murcia y Jerez), sin duda Išbīliya es la mejor documentada en las fuentes árabes. Ello se manifiesta en la existencia de un registro textual relativamente amplio y diverso, en el que se distinguen tres grandes grupos de fuentes literarias, integradas por las narraciones cronísticas, los repertorios de ulemas y las manifestaciones poéticas. De ellos, como ya se ha dicho, el primero es el único que ha sido explotado de una forma algo más sistemática, mientras que el segundo se ha aprovechado de manera sólo parcial y el tercero, en cambio, apenas ha sido objeto de una atención específica.

Esta superior disponibilidad de información se explica, sin duda, debido a la propia relevancia urbana de Išbīliya, que la convierte en objeto de atención preferente por parte de los autores árabes. Su primacía constituye un aspecto al que se refieren de manera explícita distintas fuentes elaboradas en períodos próximos a la fecha de 1248. Así lo hace, por ejemplo, al-Šaqundī, que murió en ella en $629 \mathrm{~h} / 1231-32$, en su epístola de elogio de al-Andalus, donde la identifica como la ciudad más grande e importante de dicho país (akbar mu-

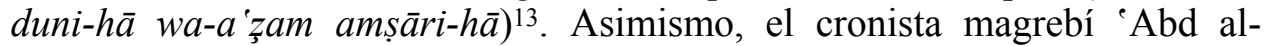
Wāhid al-Marrākuš̄in, afirma que 'Sevilla es la capital de al-Andalus en la actualidad' (hạdirat al-Andalus fi waqti-nā hāda a), siendo así que dicho autor estuvo en al-Andalus en varias ocasiones y que terminó de escribir su crónica en el año $621 \mathrm{~h} / 1224^{14}$. Podemos añadir el testimonio de un autor oriental

\footnotetext{
12 Sobre dicho proceso, véase GARCÍA SANJUÁN, 2016.

13 AL MAQQARĪ, Naf̣, vol. 3: 214; trad. GARCÍA GÓMEZ, 1976, 124.

14 AL-MARRĀKUŠİ, $M u$ 'ŷib, 272; trad. HUICI MIRANDA, 1955, 305.
} 
como Yāqūt al-Ḥamawī, que murió en 626 h/1229, quien en su extenso diccionario toponímico afirma que «no existe en al-Andalus otra ciudad mayor que ésta hoy en día» (laysa bi-l-Andalus al-yawm a z̧am min-hā) y que 'en ella radica la sede del poder y su asiento» (bi-hā qā'idat mulk al-Andalus wasarīi-hi $)^{15}$. Así pues, la centralidad de Išbīliya como núcleo urbano principal de al-Andalus constituye un aspecto que manifiestan de forma unánime fuentes árabes elaboradas en fechas inmediatamente anteriores al año 1248, tanto de autores andalusíes como magrebíes y orientales.

La citada excepcionalidad resulta doble, por cuanto se manifiesta, no sólo en la mayor cantidad de textos árabes que informan sobre su conquista, sino en la calidad de la información que los mismos aportan, muy superior al de Córdoba y Jaén, las otras dos grandes ciudades andalusíes que fueron tomadas por Fernando III. Disponemos de tres textos pertenecientes a sendos autores magrebíes, ninguno de ellos coetáneo a los hechos, aunque, en algunos casos, podemos suponerlos bien informados. Se trata de textos elaborados desde perspectivas distintas y que registran datos diferentes, aunque, en cierta forma, resultan complementarios.

Al igual que en los casos de Córdoba y Jaén, la fuente árabe más extensa y detallada sobre el asedio y conquista de Sevilla es el cronista meriní Ibn 'Idāâ̄i. No obstante, la diferencia respecto a esas dos ciudades resulta notable, pues dicho autor se extiende de manera más prolija al hablar de Išbīliya. En realidad, se trata de una de las mejores descripciones registradas en fuentes árabes de la caída de una ciudad andalusí en manos cristianas y, sin duda, de la más completa respecto al caso específico de las andaluzas. El texto va acompañado de un largo poema escrito por un autor llamado Abū Mūsà Hārūn ibn Hārūn, del cual cita setenta versos, en los que lamenta la situación de la población de la ciudad durante el asedio ${ }^{16}$.

La relevancia de Ibn 'Id̄ārī radica en dos aspectos, pues a la mayor prolijidad de su narración y a la presencia de dicho poema se añade la circunstancia de tratarse de un cronista que parece particularmente bien informado sobre las circunstancias internas de la ciudad, tal y como revelan los detalles que aporta respecto a las devastadoras consecuencias del asedio sobre la población, lo cual permite plantear la hipótesis de que hubiese podido disponer de información de procedencia local. A este respecto existe un detalle revelador sobre el que considero necesario llamar la atención. Me refiero a un texto en el que Ibn 'Id̄ārī narra los prolegómenos de la denominada "revuelta mudéjar» de 1264, varios años después, por tanto, de la caída de Išbīliya. Refiriéndose a la visita que ese año realizó a la ciudad Muhammad I de Granada para renovar

15 YĀQŪT, $M u$ 'ŷam, vol. 1: 232; trad. ABD AL-KARIM, 6 (Granada, 1974): 70.

16 IBN 'IDĀRİ, Bayān, 380-384; trad. HUICI MIRANDA, 1953-54, vol. 2: 187-189 (no traduce el poema). 
el pacto establecido en 1246 con el rey Fernando III, Ibn 'Id̄ārī utiliza la palabra atrunkāt, con la que designa la empalizada que Alfonso X pretendía haber construido para proteger al soberano nazarí durante su estancia ${ }^{17}$.

La presencia de este latinismo o voz de origen romance en la narración parece sugerir que Ibn 'Id̄ārī pudo disponer de informadores locales para la elaboración de esa narración. No resulta improbable pensar que, entre ellos, pudieran contarse algunos de los miles de emigrados sevillanos que se instalaron en ciudades del Magreb tras la caída de la ciudad en manos cristianas. Es posible, por lo tanto, que esos supuestos informadores también le suministrasen algunos de los datos que Ibn 'Idāāī inserta en su narración de la conquista, en la que revela detalles exclusivos sobre los padecimientos de la población durante el asedio. No obstante, a pesar de ello, su relato contiene, como veremos a continuación, ciertas inconsistencias, en concreto respecto a detalles de la cronología.

El segundo texto narrativo en importancia procede del diccionario geográfico de al-Himyarī, en el marco de la entrada correspondiente al topónimo «Išbîliya». Al igual que el anterior, este texto debe, asimismo, considerarse excepcional ${ }^{18}$, ya que, pese a su mayor brevedad y concisión, contiene datos inéditos en otras fuentes árabes pero que coinciden con el relato de la Estoria de España. Así, por ejemplo, al-Himyarī aporta en relación con Išbīliya la única descripción en una fuente árabe del proceso de expulsión de la población de una ciudad andalusí tras su conquista por los cristianos. El texto fue objeto de una muy conocida traducción al francés por E. Lévi-Provençal ${ }^{19}$, del cual se hizo, con posterioridad, una versión al castellano ${ }^{20}$. Dada su relevancia, ofrezco, a continuación, mi propia lectura, siguiendo la edición del citado investigador francés ${ }^{21}$ :

En el año 646, durante el mes de ša bān, el enemigo se apoderó de la ciudad de Sevilla después de varios meses de asedio, durante el cual la situación de la población fue empeorando y resultó presa del temor hasta perder la esperanza de recibir ayuda. Finalmente decidieron entregar la ciudad al enemigo y abandonarla. Así se hizo y Alfunš les otorgó un plazo para permitirles organizar el transporte de los bienes que pudieran llevarse. Luego salieron de la ciudad, que permaneció vacía durante tres días. El tirano los hizo acompañar por un contingente de caballería hasta lugares donde se encontraron seguros. Era un rey justo y con sentido político y se dice que, cuando murió, fue enterrado en la alquibla de la gran mezquita aljama.

17 IBN 'IDĀR̄i, Bayān, 431; trad. HUICI MIRANDA, 1953-54, vol. 2: 286. Véase GARCÍA SANJUÁN, 2004.

18 A pesar de ello, fue omitido por BENABOUD, 2000, cuyo estudio se basa, precisamente, en la perspectiva de las fuentes árabes.

19 LEVI-PROVENÇAL, 1938, 28.

20 MAESTRO GONZÁLEZ, 1963, 53-54.

21 AL-HiMYARI, Rawd, 22. 
Pese a su laconismo, este texto presenta una caracterización de la conquista que resulta ampliamente consistente con el relato de la Estoria de España respecto a varias cuestiones, entre ellas la cronología, las condiciones de la capitulación y el destino de la población local.

El tercer texto sobre la caída de la ciudad en manos cristianas corresponde a Ibn Jaldūn, célebre polígrafo tunecino de origen sevillano, el cual, al igual que al-Himyarī, también registra datos inéditos en otras fuentes árabes pero coincidentes con la Estoria de España, algo que, probablemente, se explica por el fuerte arraigo sevillano de su linaje, uno de cuyos miembros, Yahyà ibn Jaldūn, estuvo entre los últimos dirigentes de la ciudad, como él mismo señala. El texto se inserta en la parte de su extensa crónica relativa a la dinastía ḥafșí de Túnez, cuya soberanía fue reconocida en Išbīliya en vísperas de la conquista cristiana, al igual que en otras ciudades de al-Andalus. Tras mencionar la llegada de Abū Fāris ibn Abī Hafș, gobernador enviado por el emir Abū Zakariyā', Ibn Jaldūn señala que, en el año 643 h/1245-46, Ibn al-Ŷadd se rebeló en su contra y lo deportó a Ceuta, haciéndose con el gobierno de la ciudad y estableciendo un pacto con «el tirano», Fernando III. Debido a ello, Ibn al-Ŷadd fue asesinado por orden del caíd Šafāf, el cual volvió a llamar al depuesto gobernador hafsí.

A partir de este punto, Ibn Jaldūn introduce su descripción sobre la caída de Išbīliya en manos cristianas, en la que destaca como elemento característico el predominio de una perspectiva magrebí, ya que se trata de un relato realizado desde la óptica de los intereses y del papel desempeñado por Abū Zakariyā'. El texto ha sido traducido al francés, al menos, en dos ocasiones: primero en el resumen de la crónica realizado por el barón McGucking de Slane 22 , y más recientemente, en la versión publicada por Abdesselam Cheddadi ${ }^{23}$. A continuación ofrezco mi propia lectura, que difiere de las anteriores en ciertos aspectos ${ }^{24}$ :

Debido a ello, el tirano se indignó y se dirigió contra ellos. Tras apoderarse de Carmona y Marchena, se dispuso a asediarlos. Aunque le solicitaron un pacto (șulh), él lo rechazó. El gobierno de la ciudad (balad) había quedado en manos de un consejo (šūrà) integrado por el caíd Šafāf, Ibn Šu ayb, Yahyà ibn Jaldūn, Mas ēu ibn Jiyār y Abū Bakr ibn Šurayḥ, si bien la última palabra correspondía al jeque Abū Fāris ibn Abī Ḥafṣ. Durante dos años soportaron el asedio, en el que participó Ibn al-Aḥmar junto a las tropas del tirano. El emir Abū Zakariyā' les envió ayuda y, además, dispuso una flota cuyo mando fue confiado a Abū-l-Rabīe ibn al-Guraygir al-Tinmlalī, a quien ordenó dirigirse a Ceuta para que aprestaran su flota, dirigiéndose juntos hacia el río de Sevilla. Pero la flota del tirano logró ven-

22 DE SLANE, 1852-56, vol. 2: 321-322.

23 CHEDDADI, 2012, 470.

24 IBN JALDŪN, 'Tbar, vol. 6: 346-347. 
cerlos en el puerto ${ }^{25}$ y hubieron de regresar. El enemigo se apoderó de ella mediante capitulación (șulh) en el año 646, habiéndolos ayudado Ibn al-Aḥmar con tropas y provisiones. El tirano puso al frente de los mudéjares (ahl al-daŷn $)^{26}$ de la ciudad a 'Abd al-Ḥaqq ibn Abī Muḥammad al-Bayāsī, de la familia de 'Abd al-Mu'min.

Algunos aspectos de esta narración coinciden con detalles de la Estoria de España, en particular, los nombres de dos de los integrantes del consejo de gobierno de la ciudad (Axataf y el arráez Abenxueb, cap. 1122), la presencia del rey de Granada junto a Fernando III, que la crónica alfonsí vincula con la toma de Alcalá de Guadaíra (cap. 1072), y el episodio del envío de una flota procedente de Tánger (Taniar) y de Ceuta integrada por más de treinta naves, que fue derrotada por Ramón Bonifaz (cap. 1078).

Ibn Jaldūn menciona la conquista de Sevilla en otras ocasiones a lo largo de su extensa crónica. Pese a la naturaleza casi telegráfica de sus datos, parte de la información que aporta resulta de extraordinario interés, debido a su naturaleza exclusiva, como ya se ha indicado. Así, en la parte relativa a la dinastía nazarí, Ibn Jaldūn vuelve a reiterar la presencia de su primer soberano junto a los cristianos en el asedio de Išbīliya. Tras mencionar la caída de Córdoba, señala, refiriéndose a Fernando III27:

Luego, en el año 46, alcanzó Sevilla. Junto a él se encontraba Ibn al-Aḥmar, debido a su resentimiento contra Ibn al-Ŷadd. Tras un asedio de dos años, se apoderó de ella mediante capitulación (șulh), adueñándose, además, de sus fortalezas y territorios. También tomó Tejada ${ }^{28}$ de manos de Ibn Kumāša.

Ibn Jaldūn menciona por tercera vez la participación de Muḥammad I cuando habla sobre la dinastía meriní, volviendo a insistir en que su intención era dañar a la población sevillana (nikāyatan li-ahli-hā). Sin duda, esta actitud indica su fuerte resentimiento contra Sevilla, que debe relacionarse con hechos sucedidos años atrás, cuando la ciudad no aceptó su gobierno, poniéndose de lado de Ibn $\mathrm{Hūd}^{29}$.

25 La edición manejada trae el término marsiya, aunque debe tratarse, en realidad, de marsà ('puerto'). De Slane tradujo, tentativamente, por 'empeché par la flotte chrétienne de pénétrer jusqu'au port [de Saint-Lucar]'. Por su parte Cheddadi entiende erróneamente este término como 'Mursiya' y traduce por 'Murcia', algo que resulta a todas luces ilógico.

26 El texto editado trae, a mi juicio por error, ahl al-dajan. Véase más adelante la explicación de este hecho.

27 IBN JALDŪN, 'Ibar, vol. 4: 205; trad. GAUDEFROI-DEMOMBYNES, 12 (París, 1898): 325. AL-MAQQAR $\bar{I}, N a f h$, vol. 1: 448, reproduce parcialmente este texto (tumma nāzala Išbüliya sanat sitta wa-arba'īn wa-Ibn al-Aḥmar ma'a-hu țumma dajala-hā șulhan).

28 En lugar de TTalyāṭa (Tejada), el texto editado trae Țulayțula (Toledo).

29 IBN JALDU்N, Ibar, vol. 7: 225; trad. DE SLANE, 1852-56, vol. 4: 73; trad. CHEDDADI, 2012, 1058. 
A los tres autores magrebíes citados (Ibn 'Idāāī, al-Ḥimyarī e Ibn Jaldūn) cabe añadir el cronista meriní Ibn Abī Zare que representa el último eslabón en la cadena de fuentes narrativas y el cual resume un acontecimiento tan importante en la historia de al-Andalus en una telegráfica frase de cuatro palabras en el texto árabe, que se convierten en ocho en la traducción al castellano: en referencia al año $646 \mathrm{~h}$, afirma que «el enemigo se apoderó de la ciudad de Sevilla» (malaka al-'aduww madīnat Išbinliya) ${ }^{30}$. La crónica anónima al-Dajīra al-saniyya, atribuida a dicho autor, contiene también datos puntuales de interés, así como el poema de Ibrāhīm ibn Sahl al-Isrā'ilī, según veremos a continuación.

Aunque, sin duda, constituyen las fuentes de información principales, los textos narrativos no agotan el elenco literario árabe sobre la toma de Sevilla. A ellas deben añadirse los repertorios biográficos de ulemas, sobre todo el del valenciano Ibn al-Abbār, en los que se registran datos de individuos que vivieron en la ciudad durante su asedio o que formaron parte de los exiliados tras la conquista, así como los textos poéticos, que expresan una perspectiva emocional en relación con lo que podemos denominar como el drama de la pérdida de Išbīliya.

A diferencia de lo realizado respecto a los textos narrativos, no voy a referirme ahora de manera detenida a estos dos grupos de fuentes, sino que, en lugar de ello, por motivos de espacio, me centro directamente en el análisis de la información del registro literario árabe en relación con tres aspectos principales: la secuencia cronológica del paso de la ciudad de manos musulmanas a cristianas, la visión dramática de la pérdida de la ciudad y el destino de la población vencida.

\section{SECUENCIA CRONOLÓGICA DEL PASO DE LA CIUDAd DE MANOS MUSUlMANAS A CRISTIANAS}

Uno de los aspectos más complejos de la conquista de Sevilla radica en la cronología, sobre todo debido a la existencia de ciertas discrepancias en la información que suministran los registros textuales árabe y castellano. En este último caso, las cosas resultan relativamente sencillas, dado el predominio de un único relato, el de la Estoria de España. En cambio, la mayor diversidad de las fuentes árabes arroja una cantidad muy superior de referencias cronológicas, no todas las cuales coinciden entre sí. Aunque tradicionalmente se han interpretado estas discrepancias como producto de relatos divergentes, a mi juicio, sin embargo, se trata de una mera apariencia, de tal modo que las informaciones procedentes de ambos registros son perfectamente compatibles.

30 IBN ABĪ ZAR', Rawd, 277; trad. HUICI MIRANDA, 1964, vol. 2: 529. 
Sevilla pasó a manos cristianas bajo la modalidad de capitulación precedida de un asedio cuyo rasgo principal fue su muy larga duración, el más prolongado en la conquista de una ciudad musulmana en la península ibérica, algo que se explica por la propia envergadura de la ciudad, cuya muralla, de siete $\mathrm{km}$ de longitud, abarcaba un recinto urbano de casi trescientas hectáreas $^{31}$. Debido a este hecho y a su propia magnitud demográfica, el tránsito al dominio cristiano no se realizó mediante un solo acto, sino que requirió una secuencia de varios pasos, dados en momentos sucesivos, en los cuales se fueron ejecutando acciones distintas mediante las que los conquistadores completaron su control.

Frente al carácter fragmentario de los textos árabes, el relato de la Estoria de España presenta la ventaja de suministrar un relato completo, a través del cual resulta posible establecer la secuencia global del tránsito de la ciudad del dominio musulmán al dominio cristiano, con sus respectivas cronologías. Ese proceso puede resumirse de la forma siguiente:

- Asedio de la ciudad (cap. 1083-1122).

- Acuerdo de capitulación, en el que Fernando III exigió 'quel vaziasen la uilla et que gela dexauan libre et quita' (cap. 1123).

- Entrega del alcázar y colocación de la enseña regia en la torre, 23 de noviembre de 1248, día de San Clemente (cap. 1123).

- Concesión de un mes de plazo para que los musulmanes pudieran vender sus bienes (cap. 1124).

- Entrega de las llaves de la ciudad y evacuación de la misma (cap. 1124).

- Entrada del rey en la ciudad, 22 de diciembre de 1248, día en el que se conmemora la traslación a León del cuerpo de San Isidoro de Sevilla (cap. 1125).

A diferencia de la Estoria de España, las fuentes árabes no distinguen entre los diversos pasos que integraron esa secuencia. Cuando mencionan la caída de una ciudad en manos de los cristianos, los autores árabes suelen utilizar de forma genérica los distintos términos que expresan la noción de «conquista» (tagallub, istila $\bar{a}$ ) o simplemente el de «entrada» (dujūl), los cuales no permiten matizar de manera precisa casos como el de Sevilla, en el que el paso de la ciudad de unas manos a otras no se verificó en un único acto. A ello se añade, como ya he dicho, el problema de las distintas fechas en las que dichos textos sitúan la «conquista» o la «entrada» de los cristianos en la ciudad.

31 GARCÍA FITZ, 2000, 128. 


\section{EI asedio}

La Estoria de España afirma que Fernando III tuvo sitiada la ciudad de Sevilla durante dieciséis meses (cap. 1128), una duración que coincide con lo que establecen los propios documentos de la cancillería fernandina. A mediados de julio de 1247, las tropas castellanas cruzaron el Guadalquivir a la altura de Alcalá del Río e instalaron su primer campamento en la Torre del Caño, que se localizaría, según J. González, en la Cruz del Campo. Un privilegio real acredita que el 26 de julio de 1247, Fernando III ya estaba asentado frente a la ciudad, estableciendo el 20 de agosto su campamento definitivo en el llano de Tablada ${ }^{32}$. Por lo tanto, los dieciséis meses de asedio habrían transcurrido entre julio de 1247 y noviembre de 1248 .

Esta cronología del cerco resulta bastante compatible con lo que establecen las fuentes árabes, con escaso margen de diferencia. Algunas se limitan a ofrecer indicaciones genéricas, señalando al-Ḥimyarī que duró 'unos meses». En cambio, otras resultan más precisas. A este respecto, la fuente más importante es, sin duda, la Takmila, el repertorio biográfico del célebre polígrafo valenciano Ibn al-Abbār, coetáneo a los hechos. La obra del citado autor registra varios textos de indudable valor. El primero de ellos, sobre el que llamó la atención, por vez primera, R. Valencia ${ }^{33}$, pertenece a la biografía de un personaje fallecido durante el asedio y se trata de un testimonio decisivo para fijar la cronología de la caída de la ciudad. Refiriéndose al fallecimiento de dicho ulema, Ibn al-Abbār señala ${ }^{34}$ :

Murió durante el asedio de los cristianos a Sevilla, a comienzos del año 646. El lunes 5 de $\check{s} a$ 'bān de ese año, el tirano, señor de Castilla, se apoderó de ella mediante capitulación, tras un asedio de un año y cinco meses, aproximadamente. También se dice que murió en $\underline{d} \bar{u}-l-q a^{\prime} d a$ del año 45 y que en $r a b \bar{l}^{\prime}$ I de ese año los cristianos empezaron el asedio.

La fecha que el polígrafo valenciano señala para la toma de la ciudad (5 $\check{s}$ a bān $646 \mathrm{~h} / 23$ noviembre 1248), así como la propia duración aproximada de diecisiete meses que atribuye al asedio, nos permite situar su comienzo en el mes de $r a b{ }^{\prime}$ I de 645 (6 julio-4 agosto 1247), justo la fecha que él mismo indica al final del texto citado. Gracias a este testimonio podemos afirmar que la Takmila constituye una de las fuentes árabes más importantes para fijar la cronología de la conquista de Sevilla. No parece casual que sea un andalusí el

32 GONZÁLEZ, 1951, vol. 1: 191 y 193; GARCÍA FITZ, 2000, 144; GONZÁLEZ JIMÉNEZ, 2006, 214.

33 VALENCIA, 1988, 34.

34 Se trata de `Abd Allāh ibn Qāsim, conocido como al-Ḥarrār. Véase apéndice, nº 2. 
único autor árabe que establezca con total precisión la fecha que coincide con la que registra la Estoria de España. Frente al ya comentado predominio de fuentes magrebíes, la superior exactitud de Ibn al-Abbār sugiere la importancia que tendría poder disponer de fuentes narrativas locales datadas en el siglo XIII, una época decisiva en el destino de al-Andalus.

El propio autor de la Takmila registra otro dato de importancia, hasta ahora no integrado en el análisis historiográfico y relativo, en este caso, a 'Umar ibn Muhammad ibn 'Umar ibn 'Abd Allāh al-Azdī al-Šalūbīn (o al-Šalūbīnī), gran experto en gramática árabe, el cual habría muerto durante el asedio, a mediados del mes de șafar del año $645 \mathrm{~h}$, es decir, hacia el 22 de junio de $1247^{35}$, diecisiete meses antes del 23 de noviembre de 1248, cuando se produjo la entrega del alcázar, corroborándose, así, la duración del cerco.

Las informaciones de Ibn al-Abbār quedan parcialmente corroboradas en la descripción de Ibn 'Idāāî, quien de modo explícito atribuye al cerco la misma duración, un año y cinco meses, si bien, a diferencia del autor valenciano, el cronista magrebí revela cierta inconsistencia en el manejo de la cronología. En efecto, en dos ocasiones señala que, aunque los cristianos habían comenzado a devastar el territorio un año antes, el asedio comenzó en ŷumādà I del año 645 de la hégira es decir, entre el 3 de septiembre y el 2 de octubre de 1247. Sin embargo, la duración de diecisiete meses que le atribuye no encaja con la propia fecha de entrega de la ciudad y/o salida de la población que él mismo cita, el 27 de ramadán de 646 h (13 enero 1249). Si el asedio comenzó en la fecha citada y duró diecisiete meses, significa que hubo de terminar entre el 3 de febrero y el 2 de marzo de 1249. Esta discordancia obliga a admitir, por lo tanto, que Ibn 'Idāâ̄ no es totalmente consistente en la cronología que maneja.

\section{La capitulación y la entrega de la ciudad}

El largo asedio finalizó con la capitulación, un aspecto en el que, como hemos visto, también existe una total unanimidad entre los dos registros textuales, árabe y castellano. Coincidiendo con el relato de la Estoria de España, que fecha la entrega del alcázar el 23 de noviembre, varias fuentes árabes sitúan la conquista de la ciudad en el mes de ša bān de 646 h (19 noviembre18 diciembre 1248). Así lo hace al-Ḥimyarī, sin precisar el día exacto, a diferencia de Ibn al-Abbār, quien, como hemos visto antes, establece el lunes 5

35 IBN AL-ABBĀR, Takmila, ed. Codera, vol. 2: 657, nº 1829; ed. al-Harrās, vol. 3: 160, $\mathrm{n}^{\circ} 400$ (ambas ediciones presentan variantes textuales importantes); AL-MARRĀKUŠ̄̄ vol. 5/2: 464, $\mathrm{n}^{\mathrm{o}}$ 807, señala una fecha ligeramente posterior; IBN AL-ZUBAYR, Șila, ed. Lévi-Provençal, $71, \mathrm{n}^{\circ} 128$, menciona su muerte en dicha fecha pero no alude al asedio. 
del citado mes de $\check{s} a$ 'bān, fecha que coincide exactamente con el 23 de noviembre. Esa misma data también aparece registrada en la tardía compilación de al-Maqqarī, siendo su fuente, en apariencia, el propio Ibn al-Abbār, a quien cita a continuación ${ }^{36}$.

El polígrafo valenciano vuelve a confirmar esta cronología en un texto, perteneciente a la biografía de otro célebre ulema sevillano, ‘Alī ibn Ŷābir ibn 'Alī ibn Aḥmad al-Lajmī, conocido como al-Dabbāŷ, que fue imam de la aljama de Ibn 'Adabbas, la más antigua de la ciudad. El texto señala que murió a mediados de $\check{s} a ' b \bar{a} n$ de 646 h (3 diciembre 1248), «unos ocho días después de que los cristianos entraran en Sevilla mediante capitulación» ( $b a^{\prime} d a$ an dajala al-rūm Išbüliya șulhan bi-naḥwa tamāniyat ayyām $)^{37}$. El cálculo de Ibn al-Abbār resulta compatible con el relato de la Estoria de España, ya que, contando ocho días después del 23 de noviembre, daría el 1 de diciembre, una fecha, por lo tanto, muy próxima a la de la muerte de al-Dabbāŷ.

Como permiten comprobar los textos de Ibn al-Abbār, las fuentes biográficas árabes poseen una notable importancia a la hora de establecer la secuencia del proceso que dio lugar al cambio de manos de la ciudad, que sólo quedó completado en su totalidad con la salida de la población local ${ }^{38}$. En este punto resulta necesario plantear la cuestión, antes comentada, de las aparentes discrepancias de las fuentes árabes respecto a la cronología de la caída de Išbīliya en manos cristianas.

Frente a lo que afirman al-Ḥimyarī e Ibn al-Abbār, hay tres textos árabes, todos ellos pertenecientes a autores magrebíes, que señalan una fecha posterior al mes de $\check{s} a ' b \bar{a} n$, en concreto el día 27 de ramadán de 646 h (13 enero 1249). El primero es el propio Ibn 'Idārīi: «les entregaron la ciudad y salieron de ella nobles y plebeyos y fue esto el 27 de ramadán ${ }^{39}$. En este texto, el cronista une en la misma frase dos hechos, la fecha de la rendición o entrega de la ciudad (sallamū la-hum fì-l-madīna) y la salida de sus habitantes (jaraŷa min-hà al-jāṣs min ahli-hā wa-l-'àm), indicando a continuación la fecha en la que ello sucedió. Como comentaba anteriormente, a veces la propia naturaleza de los textos árabes limita nuestra capacidad de interpretación. En este caso concreto no podemos estar seguros de si Ibn 'Id̄ārī se refiere con esa fecha a los dos hechos que menciona o sólo al segundo de ellos, es decir, la salida

36 AL-MAQQARĪ, Nafh, vol. 4: 472.

37 IBN AL-ABBĀR, Takmila, ed. Codera, vol. 2: 683, $\mathrm{n}^{\circ} 1910$ (sólo indica el mes de $\check{s} a$ 'bān); ed. al-Harrās, vol. 3: 240, $\mathrm{n}^{\circ} 603$. De nuevo ambas ediciones presentan importantes variantes. Citado por VALENCIA, 1998, 38 (ed. de Codera).

38 Aunque no falta algún caso de confusión en el manejo de estos textos. Así sucede en el caso de BENABOUD, 2000, 78 y 82, en relación con un personaje biografiado por ALMARRĀKUŠİ, Dayl, vol. 6: 54, n ${ }^{\circ} 102$, respecto al que el historiador marroquí afirma que murió en $646 \mathrm{~h}$, mientras que, en realidad, su fuente señala que sucedió en $664 \mathrm{~h}$.

39 IBN 'IDĀR̄i, Bayān, 384; trad. HUICI MIRANDA, 1953-54, vol. 2: 188. 
de la población, opción que, a priori, parece más plausible, tanto desde el punto de vista de la propia gramática como a los hechos históricos.

En su narración del califato de al-Sa ${ }^{\top} \overline{1} d$, Ibn Jaldūn menciona esa misma fecha, siendo la única ocasión en la que fija una cronología exacta de la conquista: el citado día 27 de ramadán «se produjo la conquista de Sevilla por el tirano» (kāna istilā' al-țāgiya 'alà Išbìliya $)^{40}$. Asimismo, en la única mención que contiene al respecto, la crónica anónima al-Dajīra al-saniyya se limita a reseñar, en estilo telegráfico, que la noche del 27 del mes de ramadán «los cristianos entraron en la ciudad de Sevilla» (dajala al-nașārā madīnat Išbïliya) $\rangle^{41}$.

Por lo tanto, las fuentes árabes establecen dos fechas de la caída de Išbīliya, el 5 de $\check{s} a$ 'bān de $646 \mathrm{~h} / 23$ de noviembre de 1248 y el 27 de ramadán de ese mismo año musulmán, equivalente al 13 de enero de 1249. Mientras que la primera coincide con la que señala la Estoria de España respecto a la entrega del alcázar, la segunda no aparece mencionada en el relato de la crónica castellana. La existencia de esa dualidad cronológica supone, en apariencia, una discrepancia difícil de comprender, tratándose de un hecho tan conocido como la pérdida de la que, en ese momento, era la ciudad islámica más importante de la Península, hasta poco tiempo atrás capital del califato almohade en al-Andalus. A mi juicio, hay razones para pensar que la discrepancia es puramente aparente, de tal modo que cada una de ambas fechas se refiere, en realidad, a momentos distintos en el tránsito de la ciudad del dominio musulmán al cristiano.

Como ya se ha dicho, el relato de la Estoria de España afirma que, tras la entrega del alcázar el 23 de noviembre, los moros «demandaron plazo al rey para vender sus cosas, las que non podian leuar; et fue un mes el que ellos demandaron, et el rey ge lo dio» (cap. 1124). Este texto coincide con la información que aporta al-Himyarī respecto a la concesión por Fernando III de un plazo (âyalla-hum) para que los musulmanes pudieran organizar la evacuación de la ciudad. Dicho plazo se cumplió el día 22 de diciembre, día en el que, según la propia crónica castellana, se produjo la entrada del rey en la ciudad (cap. 1125).

$\mathrm{Al}$ igual que la entrega del alcázar simbolizaba la rendición de la ciudad, la entrada del rey de Castilla materializaba el cambio de dominio en su gobierno. Quedaba, sin embargo, un último requisito para completar su traspaso completo a manos cristianas. De acuerdo con los términos de la capitulación, la población local debía abandonarla. Aunque, sin duda, una parte habría comenzado a salir desde el mismo momento de la rendición, muchos debieron

40 IBN JALDŪN, Ibar, vol. 6: 305; trad. DE SLANE, 1852-56, vol. 2: 246; trad. CHEDDADI, 2012, 412 (traduce 'le 26 du mois de ramadân').

41 Al-Dajīra, 73. 
quedarse para tratar de vender sus bienes antes de partir. Terminado el plazo el 22 de diciembre, era obligatorio que todos los musulmanes se marchasen.

Ahora bien, con toda probabilidad, esa evacuación debió exigir un tiempo para poder completarse. Recordemos que Išbīliya era en ese momento la ciudad más importante de al-Andalus y, por lo tanto, de toda la Península. Añádase a ello que tanto las fuentes cristianas como árabes indican que Fernando III organizó un dispositivo para facilitar la evacuación, algo que debió exigir, asimismo, ciertos preparativos. Los veinte días transcurridos desde el 22 de diciembre hasta el 13 de enero debieron ser el tiempo necesario para que la ciudad quedase «libre et quita», como Fernando III la había exigido en el momento de la capitulación.

Esta interpretación de los textos narrativos se confirma a través de los repertorios de ulemas. De nuevo debemos volver a la figura, antes mencionada, del almocrí sevillano 'Alī ibn Ŷābir ibn 'Alī al-Lajmī, conocido como alDabbāŷ, cuyos biógrafos divergen respecto a la fecha exacta de su fallecimiento. Tanto Ibn Abī-l-Rabī ${ }^{\mathrm{e}}$, autor sevillano, como Ibn al-Zubayr señalan que se produjo el día 21 de $\breve{s} a b \bar{a} n$ (9 diciembre) y añaden a continuación: «nueve días antes de la salida de los musulmanes, aproximadamente» (qabla jurūŷy al-muslimīn min-hāa $)^{42}$. Según este texto, la salida habría comenzado hacia el día 18 de diciembre, fecha muy próxima a la del 22 de diciembre, en la que se produjo la entrada de Fernando III y el comienzo del éxodo definitivo de los musulmanes sevillanos. Por su parte, al-Marrākušī indica la misma fecha, pero el comentario que añade es ligeramente distinto al anterior, «nueve días antes de que los cristianos (Dios los destruya) conquistaran la ciudad (Dios la recupere)». También cita la fecha que menciona Ibn al-Abbār, pero se decanta de forma explícita por la primera de ellas.

Existe un segundo texto que confirma esta lectura, de una forma incluso más precisa. Procede, de nuevo, de Ibn al-Abbār, y pertenece a la biografía del ulema Sulaymān ibn Yahyyà ibn Sulaymān ibn Badr al-Qaysī, de quien el polígrafo valenciano dice que «murió en ramadán del año 646 en el río, después de producirse la salida de la población una vez finalizado el asedio, siendo enterrado en Triana» (itrr jurūŷy al-nās min al-hișār $)^{43}$. Se trata, pues, de otra referencia bastante precisa al momento de la salida de la población local tras la conquista.

Por lo tanto, según mi propuesta, que, con anterioridad, ha sido enunciada por otros investigadores (Huici Miranda ${ }^{44}$ y R. Valencia ${ }^{45}$ ), al invocar la fecha

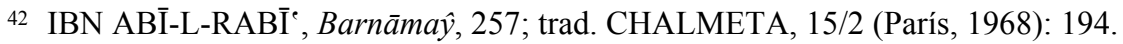

43 Apéndice $\mathrm{n}^{\circ} 16$.

44 HUICI MIRANDA, 1953-54, vol. 2: 188 (en nota): 'Se dio un plazo de un mes a los musulmanes que quisieran abandonar Sevilla y así se llega al 27 de ramaḍān, que señala el Bayān como término para la evacuación'.

45 Refiriéndose a las fechas del 5 de ša bān y el 27 de ramadán, VALENCIA, 1998, 36 señala: 'quizás sea posible pensar en que la primera correspondiera a la capitulación y la 
del 27 de ramadán de 646 h (13 de enero de 1249), las fuentes narrativas árabes están identificando el hecho de la conquista, no con la capitulación, sino con la finalización del proceso de evacuación forzosa de su población, que habría comenzado el 22 de diciembre de 1248, una vez terminado el plazo de un mes otorgado por el rey Fernando III. A mi juicio, no debe resultar casual el hecho de que las tres fuentes narrativas que registran esa fecha sean magrebíes. Tal vez fuese la que quedó en la memoria de muchos de los emigrados al Norte de África como la del final definitivo de Išbīliya, de ahí que la identificaran con la de su conquista por los cristianos y que esa idea pudiera haberse transmitido a los cronistas magrebíes. Se trata, en cualquier caso, de una fecha de gran valor simbólico en la historia de Sevilla y que, sin embargo, las fuentes cristianas no registran.

El análisis realizado nos permite apreciar la compatibilidad de los dos registros literarios, árabe y castellano, respecto a la cronología, un fenómeno que también se produce en relación con otros aspectos puntuales relativos a la conquista, como veremos a continuación. Este hecho tiene una notable importancia desde otra perspectiva, que afecta a las propias fuentes castellanas. En efecto, el relato de la Estoria de España sobre la conquista de Sevilla es considerado por ciertos especialistas parte de la denominada Crónica particular de San Fernando, escrita a comienzos del siglo XIV, a finales del reinado de Fernando IV (1295-1312), varias décadas más tarde, por lo tanto, de los hechos narrados. Según Fernández Gallardo, esta crónica se divide en dos partes. En la primera, el autor se limita a traducir el De rebus Hispaniae, de Jiménez de Rada, mientras que la segunda, que se ha denominado Seguimiento, se centra en la toma de Sevilla, constituyendo «la parte más genuina» de esta crónica, cuyo contenido procede, en buena medida, de «recuerdos y tradiciones orales» ${ }^{46}$. La citada compatibilidad entre las fuentes árabes y la narración de la Estoria de España corrobora la fiabilidad de la narración de esta crónica, pese a su cronología posterior a 1248 y la naturaleza oral de sus fuentes, revalorizando así, al mismo tiempo, la importancia de los textos árabes.

\section{LA VISIÓN DE LOS VENCIDOS: EL DRAMA DE LA PÉRDIDA DE IŠBĪLIYA}

Una de las desfavorables consecuencias del papel secundario otorgado tradicionalmente a las fuentes árabes en la reconstrucción del proceso histórico

segunda a la entrega efectiva. El período intermedio sería aprovechado para evacuar Sevilla las personas que quisieron abandonarla, que debió ser una buena parte de la población'.

46 FERNÁNDEZ GALLARDO, 32 (París, 2009): 253, 264. Agradezco al prof. F. García Fitz haberme facilitado esta referencia bibliográfica, así como sus sugerencias en relación con la relevancia de las fuentes árabes respecto a la Crónica particular de San Fernando. 
medieval en la península ibérica ha sido el predominio de la perspectiva generada por el sector de los vencedores. La manifestación principal de este fenómeno radica en la duradera hegemonía del discurso historiográfico de la Reconquista, concepto cuya dimensión más ideologizada supone una exaltación glorificadora de la conquista de al-Andalus como empresa colectiva fundacional de la nación española. La total y definitiva superación de esa situación de desequilibrio en el tratamiento de los testimonios históricos, así como la necesaria erradicación de visiones trasnochadas del pasado, hoy residuales en los medios académicos, pero persistentes en otros ámbitos, obliga a integrar en el análisis historiográfico las perspectivas de ambos registros informativos, el de los vencedores y el de los vencidos, con el fin de obtener visiones más completas y evitar, así, apriorismos y prejuicios.

Lejos del lógico triunfalismo que emana de los textos castellanos, los autores árabes nos transmiten sentimientos totalmente opuestos y que se definen en términos de tristes lamentos generados por la pérdida de una ciudad tan importante como Sevilla, precedida de un durísimo asedio de casi un año y medio de duración que causó estragos en la población local. Entre las fuentes narrativas, sin duda Ibn 'I ḋārī es el autor que resulta más elocuente en relación con este aspecto. Hace hincapié en la escasez de víveres producida por el cerco, «excepto lo que había en algunas casas de ricos», entre quienes menciona al alfaquí y cadí Ibn Manz̧ūur ${ }^{47}$. La falta de alimentos, sobre todo harina y cebada, provocó numerosas muertes por hambre: la gente, afirma, «andaban como ebrios sin estar ebrios», llegando al extremo de comer cueros ${ }^{48}$.

Una vez más, las fuentes biográficas contienen datos puntuales que nos permiten corroborar y completar los datos cronísticos. Así lo acredita el caso del ya citado ulema sevillano al-Dabbāŷ, de cuya biografía hay varias versiones en distintas fuentes, las cuales divergen en ciertos detalles, si bien todas ellas coinciden en situar su muerte en el momento de la conquista ${ }^{49}$. Tanto Ibn al-Abbār como al-Marrākušì añaden algunos datos que revelan el drama-

47 Los Banū Manz̧ūr fueron uno de los linajes sevillanos más importantes desde, al menos, el siglo XI. Según los datos que aporta el estudio de ÁVILA, 1992, 29, el único miembro de la familia que podría identificarse con el que menciona Ibn 'Idāāī es al-Faḍl ibn Yahyà ibn 'Ubayd Allāh ibn Manz̧ūr al-Qaysī, que la autora cita como alfaquí y notario, aunque no como cadí. Este personaje, según dicho estudio, vivía en el año $604 \mathrm{~h} / 1207-8$, por lo cual podría tratarse del mencionado en la crónica. Por otro lado, AL-MARRĀKUŠ̄̇, Dayl, vol. 5/2: 464, afirma que la oración fúnebre por 'Umar ibn Muhammad ibn 'Umar ibn 'Abd Allāh al-Azdī al-Šalūbīn, muerto durante el asedio, fue realizada por el cadí $A b \overline{~ Y ̂} a^{e}$ far ibn Manz̧ūr.

48 IBN 'IDĀ $\overline{\mathrm{I}} \overline{\mathrm{I}}$, Bayān, 380; HUICI MIRANDA, 1953-54, vol. 2: 187.

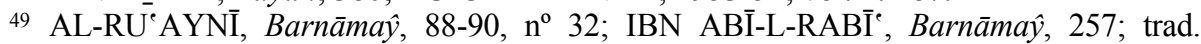
CHALMETA, $15 / 2$ (París, 1968): 194; IBN AL-ABBĀR, Takmila, ed. Codera, vol. 2: 683, ${ }^{\circ}$ 1910; ed. al-Harrās, vol. 3: 240, nº 603; IBN SA '̄̃D, Ijtiṣār , 155/156, no 37; AL-MARRĀKUŠ̄̄, Dayl, vol. 5/1: 198-201, no 394; IBN AL-ZUBAYR, Şila, ed. Lévi-Provençal, 277; ed. alHarrās, vol. 4: 142-143, nº 294; AL-MAQQARĪ, Nafh, vol. 4: 487-488. 
tismo de las situaciones vividas durante el asedio. A su oración fúnebre sólo asistieron tres personas, dada la elevada mortalidad padecida por la población a causa de las enfermedades y el hambre. Citando a Abū-l-Husayn ibn al-Sarrāŷ, ambos biógrafos afirman que su muerte se produjo a la entrada de los cristianos y que fue enterrado en su propia casa, detalle que revela la imposibilidad de organizar un cortejo fúnebre para trasladarlo a un cementerio. Su fosa tuvo que cavarse con cuchillos y fue inhumado de modo apresurado, siendo necesario suplicar para conseguir las herramientas, debido al terror que imperaba ese día ${ }^{50}$.

Si el duro trance del asedio supuso un drama para la población de Išbīliya, la pérdida de la ciudad causó una fuerte sacudida sobre las conciencias de los autores árabes. Los testimonios que mejor permiten apreciar la dimensión de este fenómeno pertenecen al género poético, uno de los más cultivados por los árabes, siendo al-Andalus un ámbito histórico en el que su desarrollo alcanzó una gran relevancia. Aunque, a priori, esta clase de textos suelen quedar, habitualmente, relegados en el análisis historiográfico, sin embargo existen ejemplos que acreditan su interés, tal y como puso de manifiesto el estudio clásico de Henri Pérès, originalmente publicado en 1937, sobre la época taifa.

El empleo de los textos poéticos como fuentes históricas adquiere un interés añadido cuando nos enfrentamos al estudio de hechos de carácter tan dramático como la guerra y sus consecuencias. En este sentido, dentro de la poesía árabe, en general, y andalusí, en particular, ha tenido un desarrollo particular el género conocido como riță al-mudun, que se define como la elegía dedicada a la pérdida de ciudades. Definido por A. Elinson como una intersección entre espacio, pérdida y memoria ${ }^{51}$, constituye una parte del fenómeno literario de la caída de al-Andalus que, sin duda, merecería ser objeto de una atención más intensa de la recibida hasta ahora.

Conocemos tres poemas directamente elaborados en relación con la pérdida de Sevilla. El primero de ellos, como se dijo, constituye una casida de sesenta versos y es obra de Abū Mūsà Hārūn ibn Hārūn, un autor poco conoci$\mathrm{do}^{52}$. Mayor difusión y celebridad ha alcanzado el poema de Ibrāhīm ibn Sahl al-Isrā'îlīi, autor árabe de origen judío y, además, sevillano, cuya casida, de la que la crónica al-Dajīra al-saniyya cita un fragmento, parece haber sido escrita durante el asedio. En este caso, disponemos de una traducción completa realizada por T. Garulo. El poema se articula en torno a dos elementos. Primero, la desesperada invocación de ayuda. Ibn Sahl contrapone la amenaza

50 En el caso de la Takmila de Ibn al-Abbār, estos detalles sobre el enterramiento de alDabbāŷ sólo figuran en la edición de al-Harrās que, como se indicó con anterioridad, presenta diferencias con la de Codera.

51 ELINSON, 2009, 16.

52 IBN 'IDĀRİ, Bayān, 381-383; HUICI MIRANDA, 1953-54, vol. 2: 187-188, omite la traducción del poema. Ha sido editado también por AL-ZAYYĀT, 1990, 698-701. ELINSON, 2009, 29, traduce algunos versos, pero no aporta información sobre la identidad del autor. 
que representan los cristianos con la esperanza que significan los combatientes $(g u z \bar{a})$ de la otra orilla y los emires árabes: «la oscuridad se cierne sobre la península y vuestras vainas guardan la mañana radiante». Asimismo, expresa la sensación de acorralamiento y opresión que experimentan los musulmanes ante la pérdida de sus tierras: «por causa de este odioso acontecimiento, no le queda al Islam más que un poco de tierra, ahora nuestra patria» (lam yabqa lil-islām gayr baqiya qad wațanat li-l-hâadit al-mutanakkir) ${ }^{53}$.

El tercero es obra del ya citado Ibn al-Abbār, uno de los principales autores andalusíes del siglo XIII, el cual tiene una importante obra poética. En una de sus composiciones el autor valenciano lamenta la caida de Išbīliya en manos cristianas, «profanaron abiertamente el vedado de Sevilla, vedado que no había sido profanado» ${ }^{54}$.

Mayor celebridad que estos tres poemas ha alcanzado, sin duda, la célebre casida nūniyya de Abū-l-Baqā' al-Rundī (m. 684 h/1285), un texto que aún hoy día sigue gozando de una enorme difusión en la tradición árabe, a tal punto que, como señalaba recientemente un investigador marroquí, «figura en los libros escolares de la mayoría de los países árabes» ${ }^{55}$. Se trata, en realidad, de una elegía por la pérdida de al-Andalus ${ }^{56}$, en la que el autor se refiere a varias ciudades, aunque con particular énfasis sobre Išbīliya, razón por la cual ha sido vinculada, en especial, con ella ${ }^{57}$, pese a que probablemente se compuso hacia $1268^{58}$, es decir, bastante tiempo después de su caída en manos cristianas. Evocando la ciudad siria de Emesa (Hims), con la que se identifica a Išbīliya en la tradición árabe andalusí, Abū-l-Baqā̄ se pregunta: «¿Dónde está Sevilla y qué fue de su alegría? ¿Dónde su río de aguas dulces, abundantes y generosas? ${ }^{59}$. Y poco más adelante, insiste, en un tono incluso más dramático: «¿Qué patria puede seducir al hombre, después de Sevilla?» ( $a$-ba'da Hims tagarru al-mar'a awțān $)^{60}$.

53 Al-Dajīra, 69-70; trad. GARULO, 1983, 141-143. Ha sido editado por AL-ZAYYĀT, 1990, 701-703. Según ELINSON, 2009, 36-37, la casida habría sido escrita a petición del gobernador de Sevilla Abū 'Abd Allāh ibn al-Sayyid ibn 'Umrān en 1242, una fecha demasiado alejada del inicio del asedio de la ciudad.

54 MARTÍNEZ DE SAN FRANCISCO, 2003, 85-86.

55 AKMIR, 2012, 218. La popularidad de esta clase de textos permite entender, entre otros factores, la fuerte atracción que al-Andalus sigue ejerciendo en el mundo árabe y musulmán, cuya desaparición se siente como una tragedia.

56 Fue editado y traducido al inglés por MONROE, 1974, 332-334, y también traducido al inglés por EBIED y YOUNG, 1976, 31-34. En español, en cambio, sólo existen versiones parciales: BOSCH VILÀ, 1984, 184-187; VALENCIA, 2010, 31-32.

57 GONZÁLEZ, 1980-86, vol. 1: 383; BOSCH VILÀ, 1984, 184-187.

58 FOULON, 2013, 142.

59 VALENCIA, 2010, 36.

60 VALENCIA, 1998, 34; 2000, 39; 2010, 32 (“¿Puede tener patria el género humano, después de haber perdido Sevilla?'). 


\section{EL DESTINO DE LA POBLACIÓN LOCAL TRAS LA CONQUISTA}

El drama humano que para la población de Išbīliya supuso el largo asedio se vio doblado con la emigración forzosa de los vencidos, a la que se refieren los dos registros literarios, árabe y castellano. Este caso particular se enmarca dentro del problema general del destino de la población musulmana de la Andalucía conquistada por Fernando III y Alfonso X. A este respecto, resulta bien conocida la explícita mención por Ibn Jaldūn, en textos distintos, de un éxodo amplio de la población andalusí61, referencias que se enmarcan dentro del gran avance territorial de los cristianos en la Península durante el siglo XIII y que han sido invocadas por algunos investigadores como una de las evidencias que avalan la tesis de la escasez de población mudéjar en Andalucía durante la Baja Edad Media ${ }^{62}$.

Los términos en los que se estableció el acuerdo de capitulación de Išbīliya exigían la salida de su población y, en general, la historiografía se ha mostrado favorable a la tesis de su vaciamiento completo ${ }^{63}$, si bien ello no resulta incompatible con posibles permanencias puntuales. Es sabido que, desde el siglo XIII, existió una aljama mudéjar en Sevilla, en la que ya J. González consideraba natural que hubiese sevillanos, «bien por haberse evadido antes de la capitulación o por venir después, bien porque se quedasen con licencia del rey», una conclusión muy similar a la alcanzada años más tarde por Antonio Collantes ${ }^{64}$ y en la que coinciden el resto de investigadores que se han planteado el problema con posterioridad ${ }^{65}$.

Siguiendo con la metodología aplicada a lo largo del artículo, a continuación me propongo revisar los escasos datos que aportan las fuentes árabes sobre este aspecto, en las cuales, como podremos comprobar, se confirma la idea de una salida masiva de la población. Tal vez resulte apropiado comenzar refiriéndonos a un testimonio hasta ahora inédito, que se refiere al célebre ulema sevillano conocido como al-Dabbāŷ. Las distintas versiones de su biografía divergen en ciertos aspectos, pero todas ellas sitúan su fallecimiento

61 IBN JALDŪN, Riḥla, 27; trad. CHEDDADI, 1995, 33; trad. CHEDDADI, 2002, 51; IBN JALDŪN, Muqaddima, II, 17; trad. RUIZ GIRELA, 2008, 431; trad. CHEDDADI, 2002, 553.

62 GONZÁLEZ JIMÉNEZ, 1994, 130; CABRERA, 2009, 188. Ambos se refieren, en exclusiva, a la referencia procedente de al-Muqaddima, la obra más conocida de Ibn Jaldūn.

${ }^{63}$ GONZÁLEZ JIMÉNEZ, y otros 1987, 9 ('la ciudad fue absolutamente vaciada de toda su población); GONZÁLEZ JIMÉNEZ, 2006, 222 ('la ciudad fue vaciada absolutamente de toda su población').

64 GONZÁLEZ 1951, vol. 1: 364; COLLANTES, 43/1 (Madrid, 1978): 143.

65 GONZÁLEZ JIMÉNEZ, 2000, 706 ('es cierto que algunos moros pudieron permanecer en la ciudad'); GONZÁLEZ JIMÉNEZ y MONTES, 12 (Valencia, 2001-02): 56, afirman que no hay razones para creer que la expulsión fuese total 'como parece deducirse del hecho incontrastable de que, casi a raíz de la conquista, grandes ciudades, como Sevilla y Córdoba, ya contasen con comunidades mudéjares perfectamente organizadas'. 
justo en el momento previo de la caída de la ciudad. Varias de ellas registran un detalle significativo, que cito a continuación siguiendo la del autor sevillano al-Ru aynī (m. 666 h/1267-68), debido a que resulta la más próxima a dicho personaje, pues fue discípulo directo suyo:

Murió, Dios lo bendiga, poco antes del final del asedio de Sevilla, y una de sus plegarias fue que no lo sacaran de la ciudad ni tener que pasar lo que experimentarían quienes siguieran vivos después de él, cuando el enemigo expulsara a la población. Y Dios respondió a su plegaria. Inmediatamente después de su muerte, el enemigo (Dios lo aniquile) se apoderó de la ciudad, en el año 646.

Me interesa enfatizar la relevancia de este texto debido a que revela un aspecto muy significativo. Sin lugar a dudas, la población de Sevilla era perfectamente consciente del destino que le esperaba en aquellas circunstancias, de tal modo que, en el momento de que los cristianos vencieran, se verían expulsados de ella. Era la solución habitual mediante la que se resolvían los pactos de conquista por capitulación.

En general, las fuentes narrativas ratifican la idea de una salida masiva de la población de Išbīliya en el momento de la conquista. Así lo indica Ibn 'Id̄ārī, especificando que afectó a todos los grupos sociales, aristocracia y plebe (jaraŷa min-hā al-jāṣ̦ min ahli-hā wa-l-'ām), queriendo así dar idea, probablemente, del carácter generalizado de la salida. Mucho más elocuente resulta alHimyarī, el cual afirma el completo vaciamiento de la ciudad durante tres días (aqāmat jāliya țalātat ayyām). Aunque, como hemos visto, se admite, en general, la naturaleza masiva de la expulsión, en la tradición historiográfica este aserto ha sido considerado poco verosímil en base a consideraciones relacionadas con diversos factores, entre ellos la inutilidad de un vacío semejante, la imposibilidad de una expulsión total en esas fechas o la inviabilidad de una ciudad completamente despojada de su población. Desde esta perspectiva, la idea de un vacío total durante tres días ha sido rechazada en términos de mito, afirmación irreal y puramente legendaria, incompatible con las propias características de la ciudad ${ }^{66}$, así como una «manifiesta exageración» ${ }^{67}$.

A mi juicio, sin embargo, la afirmación de al-Himyarī admite una valoración más matizada desde otra perspectiva. En primer lugar, no debemos olvidar que se trata de una fuente que denota un óptimo nivel de información, como revelan varios de los datos concretos que aporta, en total consonancia con los de la Estoria de España: la fecha de la caída de Išbīliya (̌̌a 'bān de $646 \mathrm{~h}$ ), el otorgamiento de un plazo por el rey a los vencidos, la alusión al proceso de evacuación de la ciudad y el dispositivo creado por el rey Fernan-

66 VALENCIA, 1988, 35; 1992, 323; 1998, 36; 2000, 39.

67 MONTES ROMERO-CAMACHO, 2000, 470. 
do III para acompañar a los expulsados. A ello cabría añadir la referencia al enterramiento del propio rey en la aljama de la ciudad, un aspecto inédito en otros textos árabes y que también indica el manejo de fuentes fiables por parte de al-Himyarī. Por lo tanto, la alusión al vacío total de la ciudad durante tres días podría considerase una forma verosímil, aunque, tal vez, algo hiperbólica, de expresar la naturaleza completa de la evacuación.

Las alusiones explícitas de Ibn 'Id̄ārī y al-Himyarī a la salida masiva se complementan con una referencia, hasta ahora inédita, procedente, de nuevo, de las fuentes biográficas. Se trata de un texto relativo a un personaje llamado Muhammad ibn 'Abd Allāh ibn Abī Zayn al-'Abdarī, de origen toledano, el cual ejerció como cadí de los mudéjares de su ciudad. Luego emigró a Córdoba y después se trasladó a Sevilla, donde vivió durante un tiempo, hasta que la abandonó «el año de la salida general», dirigiéndose a Ceuta, donde murió en fecha indeterminada ${ }^{68}$.

La expresión «el año de la salida general» (sanat al-jurūŷy al- 'āmma) constituye un testimonio explícito y muy elocuente de la naturaleza total de la expulsión de la población musulmana tras la conquista, confirmando, así, las referencias anteriores. Al mismo tiempo, estas informaciones de las fuentes árabes ratifican lo señalado en la Estoria de España respecto a la voluntad de Fernando III de recibir la ciudad «libre et quita». Si bien dicha crónica afirma la salida de un total de 400 mil personas (100 mil por mar hacia Ceuta y 300 mil por tierra a Jerez ${ }^{69}$ ), cifra a todas luces hiperbólica (cap. 1124), ambos destinos encuentran, asimismo, cierta confirmación en las fuentes árabes.

Los repertorios de ulemas nos permiten conocer la identidad de casi una veintena de personajes emigrados (véase apéndice) ${ }^{70}$. Al margen de la información ya señalada, el alcance de estos textos resulta muy limitado, en tanto que sólo se refieren a los integrantes del colectivo de hombres de religión, una parte minoritaria y, hasta cierto punto, elitista de la población. Más allá de dicha identidad, lo cierto es que no aportan datos muy reveladores respecto a la salida de los musulmanes, si bien permiten conocer, al menos, su destino que, en parte, coincide con lo que establece la Estoria de España.

Existe un caso singular que ayuda a entender el fenómeno que ha sido caracterizado como «emigración escalonada». Se trata de 'Ubayd Allāh ibn 'Abd al-'Azīz ibn 'Ubayd Allāh ibn 'Abd al-Malik ibn 'Ubayd Allāh ibn

68 Apéndice, $\mathrm{n}^{\circ} 8$.

69 Respecto al grupo desplazado a Jerez, debe señalarse otra coincidencia entre los dos registros literarios. Al-Ḥimyarī señala que el rey cristiano 'los hizo acompañar por un contingente de caballería hasta lugares donde se encontraron seguros', al igual que la Estoria de España, la cual indica que 'con estos enbio al maestre de Calatrava que los guio e los puso en saluo, fasta dentro a Xerez'.

70 Esta cifra supera los ulemas emigrados registrados en trabajos anteriores: VALENCIA, 1988; MARÍN, 1995. 
Jiyār al-Qurašī al-Umawī al-Išbīlī, salió de Sevilla tras su conquista, estableciéndose en Jerez durante un tiempo, después del cual se asentó en Tarifa, hasta que tuvo que abandonarla tras su conquista, el 30 de $\check{s} a w w a \bar{l}$ del año 691 h (14 octubre 1292), dirigiéndose finalmente a Ceuta, donde murió el 8 de $\mathrm{rabi}^{\prime}$ II de $692 \mathrm{~h}$ (18 marzo 1293)

La historia de este personaje recuerda mucho al de otro que aparece registrado en la Crónica de Fernando IV. Me refiero al «moro viejo» de Gibraltar que, tras la conquista cristiana de dicha plaza (1309) y antes de marcharse al Magreb, narró al rey el peregrinaje que se había visto obligado a seguir, emigrando de Sevilla a Jerez, de aquí a Tarifa y finalmente a Gibraltar, siguiendo, de este modo, un itinerario determinado por el progresivo avance de las conquistas cristianas $^{72}$. El paralelismo entre estas narraciones, procedentes de fuentes literarias árabes y castellanas, revela que, con toda probabilidad, no debió de tratarse de situaciones excepcionales.

Las referencias de Ibn 'Id̄ārī y al-Himyarī, coincidentes con la de la Estoria de España, así como las informaciones de los repertorios biográficos de ulemas, conforman un conjunto homogéneo de testimonios que permiten afirmar la idea de un vaciamiento completo o, incluso, absoluto, de la población musulmana. Sin embargo, como se ha dicho, en la Sevilla cristiana existió durante la segunda mitad del siglo XIII una comunidad mudéjar respecto a cuyos orígenes existen muy pocos datos. Las fuentes árabes aportan alguno de ellos.

Sin duda la referencia más importante corresponde a Ibn Jaldūn, cuando, en su texto principal sobre la conquista de la ciudad, afirma que: «el tirano puso al frente de los mudéjares de la ciudad a 'Abd al-Haqq ibn Abī Muhammad alBayāsī, de la familia de 'Abd al-Mu'min» ${ }^{73}$. Dado que el texto se inserta en la narración de la caída de Išbīliya, debemos asumir que cuando habla del «tirano» (al-țāgiya), el polígrafo tunecino está refiriéndose a Fernando III. No obstante, se trata de una denominación genérica válida para cualquier soberano no musulmán, por lo cual no cabría descartar por completo que la estuviese aplicando, por ejemplo, a su sucesor, Alfonso X (1252-84). En cualquier caso, como señala Rafael Valencia, la designación de un responsable al frente del colectivo mudéjar $(a h l a l-d a y \hat{n})^{74}$ indica que debía tratarse de un grupo de cierta entidad ${ }^{75}$.

71 Apéndice, $\mathrm{n}^{\circ} 18$.

72 CABRERA, 2009, 184.

73 IBN JALDŪN, 'Tbar, vol. 6: 346-347.

${ }^{74} \mathrm{La}$ edición del texto de Ibn Jaldūn dice, en realidad, ahl al-dajan, lo que, a mi juicio, constituye una confusión (del editor o del propio manuscrito) entre las consonantes árabes quinta y séptima, cuya grafía es muy similar. La palabra dajan significa 'maldad' o 'corrupción', lo cual, sin duda, explica el sentido atribuido al sintagma por DE SLANE, 185256, vol. 2: 322 ('traîtres') y CHEDDADI, 2012, 470 ('gens corrompus'), el mismo que registra VALENCIA, 1998, 36; 2000, 39.

75 VALENCIA, 1992, 324. 
La segunda referencia es mucho menos explícita que la anterior, aunque también sugiere la presencia de una comunidad mudéjar en la Sevilla del siglo XIII. El polígrafo nazarí Ibn al-Jatīb informa sobre un personaje llamado Muhammad ibn 'Al̄̄ ibn 'Abd Allāh ibn Muhammad ibn al-Hāâŷy (m. 714 $\mathrm{h} / 1314$ ), de cuyo padre se dice que era carpintero, mudéjar de Sevilla ( $\mathrm{min}$ mudaŷyanì madīnat Išbīliya) y experto en técnicas de ingeniería, el cual se trasladó a Marrakech en época del sultán meriní Abū Yūsuf al-Manșūr ibn 'Abd al-Ḥaqq (1258-1286) ${ }^{76}$. Más aún que en el caso anterior, no podemos estar seguros de si la alusión a esos mudéjares de Sevilla se refiere a la época de Fernando III o a la de Alfonso X.

En definitiva, parece bien establecido que, en consonancia con lo que estipulaban las normas bélicas de la época y con lo que el propio rey Fernando III exigió de manera explícita en el momento de la rendición, la ciudad fue vaciada de su población de una forma que podemos considerar masiva y completa. Por otro lado, aunque escasas, las referencias en fuentes árabes a una comunidad mudéjar son explícitas, pero demasiado vagas como para poder afirmar el origen local o foráneo de sus componentes, si bien la segunda opción parece más acorde con los testimonios. Como se ha dicho, no puede descartarse que algunos musulmanes pudiesen permanecer pero, frente a esta mera conjetura, consta que en época de Alfonso X hubo unos «moros alfaquíes» a los que el rey donó tierras en el repartimiento.

\section{CONCLUSIÓN}

El análisis previo nos ha permitido apreciar de forma pormenorizada las características de la información que las fuentes árabes contienen respecto a la caída de Išbīliya en manos de la Corona de Castilla en el año 646 h/124849. Frente a la función preeminente atribuida en la tradición historiográfica clásica a las fuentes castellanas, en detrimento de las árabes, consideradas secundarias, a mi juicio existen razones suficientes para establecer una mayor equiparación entre ambos registros literarios, ya que sólo su análisis combinado nos permite obtener una visión completa y global de la conquista.

En términos comparativos, la mayor diferencia que encontramos respecto a las fuentes castellanas radica en la dependencia de un único relato, el que figura en la Estoria de España. Frente a ello, las fuentes árabes comportan una superior diversidad de géneros y de autores, lo cual otorga una mayor riqueza y complejidad a su análisis. Por otro lado, considero necesario insistir en la naturaleza ampliamente compatible de ambos registros, con ciertas excepciones puntuales.

76 IBN AL-JAṬ̂̄B, Iḥ̂̄ṭa, vol. 2: 140. 
Las fuentes árabes, por lo tanto, no alteran en lo esencial el relato de la $E s$ toria de España, razón que, tal vez, permita también entender el uso restrictivo que la historiografía más tradicional ha hecho de ellas, junto a las razones antes indicadas. No obstante, a mi juicio, aportan dos aspectos de relevancia principal, uno de naturaleza más general y otro de carácter específico. Por un lado, la visión de los vencidos, lógico contrapunto al triunfalismo de los vencedores, prolongado en la tradición historiográfica más clásica a través de la versión más ideologizada de la noción de Reconquista. En el plano puramente empírico, la fecha del 27 de ramadán de 646 h/13 enero 1249, ausente del relato de la Estoria de España y que marca el final definitivo y completo de la Išbīliya árabe y musulmana, con la evacuación total de su población.

\section{APÉNDICE. Ulemas EMIGRAdOS TRAS la CONQUiSTA}

1. 'Abd Allāh ibn 'Alī ibn Muḥammad ibn Ibrāhīm al-Anșāī al-Istiŷŷ̀i, conocido como Ibn Sitārī, permaneció en Sevilla hasta que le puso asedio el tirano de Castilla, no siéndole posible abandonar la ciudad hasta que la tomó mediante capitulación, dirigiéndose a Ceuta, donde murió el 9 de șafar de 647 h (24 mayo $1249)^{77}$.

2. ‘Abd Allāh ibn Qāsim ibn `Abd Allāh ibn Muhammad ibn Jalaf, conocido como al-Harrā $\mathbf{r}^{78}$.

3. 'Abd al-Raḥmān ibn 'Alī ibn Ŷarrāḥ al-Qaysī al-Munastirī, salió de Sevilla con el resto de sus habitantes, estableciéndose en Marrakech, donde murió a mediados del año 650 h (14 marzo 1252-3 marzo 1253), o poco más tarde ${ }^{79}$.

4. 'Alī ibn Muhammad al-Kutāmī, se establece en Granada tras la conquista de Sevilla por los cristianos, donde murió en $\mathrm{rabi}^{\prime}$ II de 680 h (20 julio-18 agosto $1280)^{80}$.

5 y 6. Los ubetenses 'Alī ibn 'Abd al-Raḥmān ibn 'Alī ibn 'Abd al-Raḥmān al-Jušanī y 'Alī ibn Muḥammad ibn Muḥammad ibn ‘Abd al-Raḥnān al-Jušanī, vivieron en Sevilla hasta que la conquistaron los cristianos, emigrando a Granada, muriendo el segundo de ellos allí en raŷab de 680 h (16 octubre-14 noviembre 1281$)^{81}$.

77 IBN ABĪ-L-RABĪ , Barnāmây, 261; trad. CHALMETA, $15 / 2$ (París, 1968): 199; IBN AL-ABBĀR, Takmila, ed. Codera, vol. 2: 522, no 1461; ed. Al-Harrās, vol. 2: 299-300, no 854; IBN AL-ZUBAYR, Șila, ed. al-Harrās, vol. 3: 147, $\mathrm{n}^{\circ}$ 243. Citado por VALENCIA, 1988, 34 y MARÍN, 1995, 58.

78 IBN AL-ABBĀR, Takmila, ed. Codera, vol. 2: 519-520, $\mathrm{n}^{\circ}$ 1457; ed. al-Harrās, vol. 2: 297-298, nº 850; IBN AL-ZUBAYR, Sila, vol. 3: 146, nº 241. Citado por VALENCIA, 1988, 34.

79 IBN AL-ZUBAYR, Sila, vol. 3: 211, n 365.

80 AL-MARRĀKUŠ̄̃, Dayl, vol. 5/2: 373, nº 641.

81 AL-MARRĀKUŠİ, Dayl, vol. 5/1: 249, no 500 y 391, nº 656; IBN AL-ZUBAYR, Șila, ed. al-Harrās, vol. 4: 150, n⿳0 307, dice que el segundo se asentó en Málaga y murió allí en 680 h. 
7. Ibrāhīm ibn Aḥmad ibn 'Īsà al-Gāfiqīi, salió de su ciudad, Sevilla, cuando los cristianos se apoderaron de ella en el año $646 \mathrm{~h}$ y murió el 30 de $\underline{d} \bar{u}-l$-qa $d a$ de $716 \mathrm{~h}$ (31 febrero 1317$)^{82}$.

8. Muhammad ibn 'Abd Allāh ibn Abī Zayn al- Abdarī, toledano, vivió un tiempo en Sevilla, abandonándola el año de la salida general y asentándose en Ceuta, donde murió $^{83}$.

9. Muḥammad ibn Aḥmad ibn Muḥammad ibn Aḥmad ibn Abī Hārūn al-Tamīmī, que murió en Algeciras «justo después de la salida de los habitantes de Sevilla, en el año 46 o, según se dice, y es más correcto, en el $647 \gg{ }^{84}$.

10. Muhammad ibn Aḥmad ibn Jalīl al-Sakūn̄̄, perdió un libro en su salida de Sevilla, cuando los cristianos se apoderaron de ella ${ }^{85}$.

11. Muḥammad ibn Aḥmad ibn Jalīl al-Sakūn̄̄, murió camino de Niebla «cuando la salida de los sevillanos de la ciudad en el año $646 \mathrm{~h}{ }^{86}$.

12. Muḥammad ibn Aḥmad ibn 'Abd al-Raḥmān ibn 'Ubayd Allāh ibn al- 'Aș̣̂̄ alLajmī, sevillano, salió de Sevilla cuando los cristianos se apoderaron de ella, asentándose en Málaga ${ }^{87}$.

13. Muḥammad ibn Aḥmad ibn 'Abd al-Raḥmān al- Ubaydī, trabajaba en la administración de la ciudad hasta que se apoderaron los cristianos de ella y murió en Ceuta, el viernes 6 de $\check{s} a w w \bar{a} l$ de 646 h (22 enero 1249) ${ }^{88}$.

14. El padre del cadí Muhammad ibn Aḥmad ibn Muhammad ibn Aḥmad ibn Muḥammad ibn Aḥmad al-Ŷudāmī se trasladó de Sevilla cuando el enemigo la conquistó en 646 h, asentándose sucesivamente en Ronda, Granada y Ceuta ${ }^{89}$.

15. Muhammad ibn al- 'Awāmm al-Išbīlī, «cuando el enemigo se apoderó de Sevilla se embarcó hacia la isla de Menorca» ${ }^{90}$.

16. Sulaymān ibn Yahyyà ibn Sulaymān, murió en el río, en ramadán de 646 h (18 diciembre 1248-16 enero 1249), justo después de la salida de los musulmanes posterior al asedio, siendo enterrado en Triana ${ }^{91}$.

82 AL-BUNNĀHĪ, Marqaba, ed. Lévi-Provençal, 133.

83 AL-MARRĀKUŠĪ, Dayl, vol. 6: 509, nº 1305.

${ }^{4}$ IBN ABĪ-L-RABI' ${ }^{e}$, Barnāmây, 256; trad. CHALMETA, $15 / 2$ (París, 1968): 192; ALMARRĀKUŠİ, Dayl, vol. 6: 32, n 53. Citado por VALENCIA, 1988, 34.

85 AL-MARRĀKUŠİ, Dayl, vol. 6/2: 630-635, n 1200; IBN AL-ZUBAYR, Sila, ed. alHarrās, vol. 5: 382, $\mathrm{n}^{\circ} 152$.

86 AL-MARRĀKUŠİ, Dayl, vol. 5/2: 635-636, n 1201; IBN AL-ZUBAYR, Șila, ed. alHarrās, vol. 5: 383, n $^{\circ} 153$.

87 AL-MARRĀKUŠİ, Dayl, vol. 5/2: 673-674, nº 1269.

88 AL-MARRĀKUŠİ, Dayl, vol. 5/2: 681-682, n 1283.

89 AL-BUNNĀHĪ, Marqaba, ed. Lévi-Provençal, 153.

90 IBN SA ${ }^{\complement} \overline{I D}$, Ijtișār $r, 180, \mathrm{n}^{\circ} 49$.

91 IBN AL-ABBĀR, Takmila, ed. al-Harrās, vol. 4: 104, no 292; AL-MARRĀKUŠĪ, Dayl, vol. 4: 97-98, n 207. 
17. 'Ubayd Allāh ibn Aḥmad ibn 'Ubayd Allāh ibn Abī-l-Rabīe al-Quraš̄in, salió de Sevilla junto con el resto de sus habitantes y se estableció en Ceuta, donde murió el viernes 16 de safar de 688 h (11 marzo 1289) $)^{92}$.

18. 'Ubayd Allāh ibn 'Abd al- 'Azīz ibn 'Ubayd Allāh ibn 'Abd al-Malik ibn 'Ubayd Allāh ibn Jiyār al-Qurašī al-Umawī al-Išbīlī, salió de Sevilla tras su conquista hacia Jerez, luego se fue a Tarifa, hasta que tuvo que abandonarla tras su con-

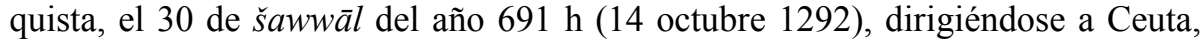
donde murió el 8 de $r a b \bar{\imath}^{`}$ II de 692 h (18 marzo 1293) ${ }^{93}$.

\section{FUENTES ÁRABES}

Anónimo, Al-Dajīra al-sanīyya fì ta'rīj al-dawla al-marīniyya, Rabat, 1972.

'Abd al-Wāḥid al-Marrākušī, Kitāb al-mu' ŷib fì taljīṣ ajbār al-Magrib, ed. R. Dozy, Leiden, 1881.

Al-Bunnāhī, Al-Marqaba al- 'ulyà, ed. E. Lévi-Provençal, Beirut, 1948; ed. y trad. A. Cuellas Marqués, Al-Marqaba al-'ulyà de al-Nubāhī (La atalaya suprema sobre el cadiazgo y el muftiazgo), Granada, 2005.

Al-Himyarī, Kitāb al-raw d al-mi țār fì jabar al-aqtāar, ed. parcial y trad. francesa E. Lévi-Provençal, La Péninsule Ibérique au Moyen Âge d'après le Kitāb ar-rawd al-mi țār fì habar al-aktāar, Leiden, 1938.

Ibn al-Abbār, Al-Takmila li-kitāb al-Șila, ed. F. Codera, Madrid, 1887, 2 vols.; ed. 'Abd al-Salām al-Harrās, Casablanca, 1995, 4 vols.

Ibn Abī Zar', Kitāb al-ānīs al-mutrib bi-rawḍ al-qirțās fì ajbār mulūk al-Magrib wata'rìj madīnat Fās,

Ibn 'I ḍārī, Al-Bayān al-mugrib (qism al-muwaḥhidīn), ed. M. I. Al-Kattān̄̄ y otros, Casablanca, 1985.

Ibn Jaldūn, Al-Muqaddima, ed. 'Abd al-Salām al-Šaddādī, Casablanca, 2005, 5 vols.

Ibn Jaldūn, Kitāb al- 'ibar, ed. Muhammad 'Alī Bayḍun, Beirut, 2003, 2ª ed., 8 vols.

Ibn Jaldūn, Riḥla. Ed. M. Ibn Tāwīt al-Ṭanŷ̀, Beirut, 2004.

Ibn al-Jaṭīb, Al-Iḥāta fì ajbār Garnātạ, ed. 'Inān Fāris, El Cairo, 1973-77, 4 vols.

Ibn al-Jậīb, A'māl al-a 'ām, ed. E. Lévi-Provençal, Beirut, 1956.

Ibn al-Zubayr, Șilat al-şila, ed. E. Lévi-Provençal, Rabat, 1938; ed. 'Abd al-Salām al-Harrās, Rabat, 1993-1995, 3 vols.

Al-Maqqarī, Nafḥ al-ṭ̂̄b, ed. Iṇsān 'Abbās, Beirut, 1968, 8 vols.

Al-Marrākuš̄i, Al-Dayl wa-l-takmila li-kitabay al-Mawṣul wa-l-Ṣila, ed. M. Ibn Šarīfa e Iḥsān 'Abbās, Rabat y Beirut, 1964-84, 8 vols.

Yāqūt al-Hamawī, Mu'ŷam al-buldān, ed. Farīd 'Abd al-'Azīz al-Ŷundī, Beirut, 7 vols.

92 IBN AL-ZUBAYR, Șila, ed. al-Harrās, vol. 3: 166, nº 281.

93 IBN AL-ZUBAYR, Șila, ed. al-Harrās, vol. 3: 167, nº 282. 


\section{TRADUCCIONES DE FUENTES ÁRABES}

Abd al-Karim, Gamal, 'La España musulmana en la obra de Yāqūt', Cuadernos de Historia del Islam, 6 (Granada, 1974).

Chalmeta, Pedro, 'Le Barnāmă̆ d'Ibn Abī Rabīe', Arabica, $15 / 2$ (París, 1968), 183-208. Cheddadi, Abdessalam, Ibn Khaldûn. Le voyage d'Occident et d'Orient, París, 1995. Cheddadi, Abdessalam, Ibn Khaldoun. Le livre des Exemples, I. Autobiographie, Muqaddima, París, 2002.

Cheddadi, Abdessalam, Ibn Khaldoun. Le livre des Exemples, II. Histoire des Arabes et des Berbères du Maghreb, París, 2012.

De Slane, MacGuckin, Histoire des berbères, París, 1852-56, 4 vols. (reed. 1999).

De Slane, MacGuckin, Les Prolegoménes d'Ibn Khaldoun, París, 1863-68, 3 vols.

García Gómez, Emilio, Andalucía contra berbería, Barcelona, 1976.

Gaudefroy-Demombynes, Maurice, 'Histoire des Benou'l-Ahmar, rois de Grenade', Journal Asiatique, XII (París, 1898), 309-340 y 407-462.

Garulo, Teresa, Ben Sahl de Sevilla. Poemas, Madrid, 1983.

Huici Miranda, Ambrosio, Al-Bayan al-Mugrib fì ijtișār ajbār mulūk al-Andalus wa

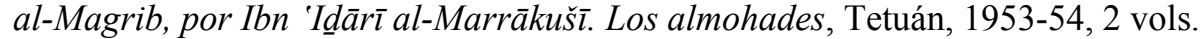

Huici Miranda, Ambrosio, Lo admirable en el resumen de las noticias del Magreb, Tetuán, 1955.

Huici Miranda, Ambrosio, Ibn Abi Zar'. Rawd al-qirtas, Valencia, 1964, 2 vols.

Maestro González, Ma Pilar, Kitab ar-Rawd al-Mitar, Valencia, 1963.

Martínez de Francisco, Santiago, Ibn al Abbar. Salvad al-Andalus y otros poemas, Madrid, 2003.

Monroe, James T., Hispano-Arabic Poetry. A Student Anthology. Berkeley, 1974.

Ruiz Girela, Francisco, Ibn Jaldún. Introducción a la historia universal (alMuqaddima), Córdoba, 2008.

\section{BIBLIOGRAFÍA}

Akmir, Abdeluahed, «La percepción del otro y las vías de la tolerancia en alAndalus», en Diego Melo Carrasco y Francisco Vidal Castro (eds.), A 1300 años de la conquista de al-Andalus (711-2011), Coquimbo (Chile), 2012; 215-226.

Ávila, M ${ }^{\mathrm{a}}$ Luisa, «Los Banū Manz̧ūr al-Qaysī», en Manuela Marín, y Jesús Zanón (eds.), Estudios Onomástico-Biográficos de al-Andalus, V, Madrid, 1992; 23-38.

Benaboud, Muhammad, «La conquista de Andalucía y de Sevilla en las fuentes árabes», en Manuel González Jiménez, (coord.), Sevilla 1248. Actas del Congreso Internacional Conmemorativo del 750 aniversario de la conquista de Sevilla, Madrid, 2000; 73-83.

Cabrera, Emilio, «Tópicos y realidades sobre la organización de Andalucía tras la Reconquista», en Antonio Malpica (ed.), Historia de Andalucía. VII Coloquio, Granada, 2009; 179-202. 
Collantes, Antonio, «La aljama mudéjar de Sevilla», Al-Andalus, 43-1 (Madrid, 1978), 143-162.

Ebied, R. Y. y Young, M. J. L., 'Abū-l-Baqā' al-Rundī and his Elegy on Muslim Spain», The Muslim World, 66-1 (1976), 29-34.

Elinson, Alexander, Looking Back at al-Andalus. The Poetic of Loss and Nostalgia in Medieval Arabic and Hebrew Literature. Leiden, 2009.

Fernández Gallardo, Luis, «La Crónica particular de San Fernando: sobre los orígenes de la crónica real castellana, I. Aspectos formales», Cahiers d'Études Hispaniques Médiévales, 32 (París, 2009), 245-265.

Foulon, Brigitte, «Paysages et nostalgie dans la poésie andalouse», Brigitte Foulon (dir.), L'écriture de la nostalgie dans la littérature arabe, París, 2013; 137-161.

García Fitz, Francisco, «El cerco de Sevilla: reflexiones sobre la guerra de asedio en la Edad Media», en Manuel González Jiménez (ed.), Sevilla 1248. Actas del Congreso Internacional Conmemorativo del 750 aniversario de la conquista de Sevilla, Madrid, 2000; 115-154.

García Sanjuán, Alejandro, "Causas inmediatas y alcance de la revuelta mudéjar de 1264-1266», en IX Simposio Internacional de Mudejarismo. Mudéjares y moriscos, cambios sociales y culturales (Teruel, 12-14 septiembre 2002), Teruel, 2004; 505-518.

García Sanjuán, Alejandro, «La conquista de Andalucía y el destino de la población musulmana. La aportación de las fuentes árabes», M. González Jiménez y R. Sánchez Saus (eds.), Arcos y la frontera andaluza (1264-1330), Universidad de Sevilla, 2016, 33-58.

González González, Julio, Repartimiento de Sevilla, Madrid, 1951, 2 vols. (reed. facísmil, Sevilla, 1998).

González González, Julio, Reinado y diplomas de Fernando III, Córdoba, 1980-86, 3 vols.

González Jiménez, Manuel, «Los mudéjares andaluces (s. XIII-XV)», Andalucía a debate y otros estudios, Sevilla, 1994; 121-154.

González Jiménez, Manuel, «Sevilla en la hora de 1248», en Manuel González Jiménez (coord.), Sevilla 1248. Actas del Congreso Internacional Conmemorativo del 750 aniversario de la conquista de Sevilla, Madrid, 2000; 703-709.

González Jiménez, Manuel, Fernando III el Santo, Sevilla, 2006.

González Jiménez, Manuel y Montes Romero-Camacho, Isabel, «Los mudéjares andaluces (siglos XIII-XV) aproximación al estado de la cuestión y propuesta de un modelo teórico», Revista d'Historia Medieval, 12 (Valencia, 2001-2), 47-78.

González Jiménez, Manuel y otros, Sevilla en tiempos de Alfonso X el Sabio. Sevilla, 1987.

Huici Miranda, Ambrosio, Historia politica del Imperio almohade, Tetuán, 19561957, 2 vols. (reedición facsími Granada, 2000).

Manzano, Eduardo, Conquistadores, emires y califas. Los Omeyas y la formación de al-Andalus, Barcelona, 2006.

Martínez Díez, Gonzalo, Fernando III (1217-1252), Palencia, 1993.

Menéndez Pidal, Ramón, Primera Crónica General, Madrid, 1977. 
Montes Romero-Camacho, Isabel, «Mudéjares y judíos en la Sevilla del siglo XIII», en Manuel González Jiménez (coord.), Sevilla 1248. Actas del Congreso Internacional Conmemorativo del 750 aniversario de la conquista de Sevilla, Madrid, 2000; 467-498.

Valencia, Rafael, «Los dirigentes de la Sevilla árabe en torno a 1248», en Andalucía entre Oriente y Occidente (1236-1492). Actas del V Coloquio Internacional de Historia Medieval de Andalucía, Córdoba, 1988; 30-36.

Valencia, Rafael, «La emigración sevillana hacia el Magreb alrededor de 1248», en Actas del II Coloquio Hispano-Marroquí de Ciencias Históricas. Historia, Ciencia y Sociedad (Granada, 6-10 noviembre 1989), Granada, 1992; 323-327.

Valencia, Rafael, «Las campanas de Abu-1-Hasan ad-Dabbach. Sevilla, 1198-1249», en Metropolis totius hispaniae. 750 aniversario incorporación de Sevilla a la corona castellana, Sevilla, 1998; 27-40.

Valencia, Rafael, «La Sevilla almohade: el espacio urbano», en Manuel González Jiménez (coord.), Sevilla 1248. Actas del Congreso Internacional Conmemorativo del 750 aniversario de la conquista de Sevilla, Madrid, 2000; 33-41.

Valencia, Rafael, El aire de Sevilla. Los refranes de la Sevilla árabe. A la sombra de Pascual de Gayangos. Discurso leido ante la Real Academia Sevillana de Buenas Letras, el día 24 de octubre de 2010, Sevilla, 2010.

Al-Zayyāt, 'Abd Allāh Muhạmmad, Rițā' al-mudun fì-l-ši 'r al-Andalusī, Bengazi, 1990.

Recibido: $24 / 05 / 2015$

Aprobado: 05/06/2015 